Monika Münnich (Lublin)

\title{
Przyczyny i cele stosowania zwrotów niedookreślonych w przepisach prawa skarbowego w okresie dwudziestolecia międzywojennego w Polsce
}

I. Ukształtowany w dwudziestoleciu międzywojennym system prawa skarbowego postrzegany bywa we współczesnym piśmiennictwie jako swego rodzaju model czy wzorzec wysokich standardów legislacyjnych tej gałęzi prawa publicznego. Wydaje się, że wysoka ocena przedwojennych rozwiązań prawnych w zakresie prawa skarbowego wynika przede wszystkim z tego, że przepisów prawa podatkowego obowiązujących w okresie PRL nie można uznawać za wzorcowe rozwiązania normatywne. Przeciwnie, jedną z cech ustroju komunistycznego była stopniowa likwidacja tego rodzaju prawa jako odrębnej gałęzi systemu prawa publicznego, pełniącej konkretne funkcje fiskalne i pozafiskalne w państwie. Z tych też względów już w pierwszych latach po roku 1989 pojawiła się w Polsce ogromna potrzeba nie tyle reformy, co budowy nowego systemu prawa podatkowego przystającego do zmieniających się politycznych, społecznych i gospodarczych uwarunkowań.

Ogólne porównanie sytuacji zaistniałych w pierwszych latach po odzyskaniu niepodległości w $1918 \mathrm{r}$. oraz w pierwszych latach transformacji ustrojowej po 1989 r. prowadzi do konstatacji, że ówcześni legislatorzy zmagali się z bardzo podobnymi problemami. W obydwu przypadkach konieczne było jak najszybsze przygotowanie szerokiej płaszczyzny przepisów prawa podatkowego, adekwatnych do nowych warunków właściwych dla ustroju państwa demokratycznego. Wydaje się, że właśnie te podobieństwa sprawiły, iż dorobek ustawodawczy polskiej myśli prawnej w zakresie prawa skarbowego z czasów II RP uznany został na początku lat 90 . XX wieku nie tylko za swego rodzaju modelowe wyzwanie legislacyjne, ale i dowód na to, że względnie spójny i sprawny system prawa podatkowego można było ukształtować w okresie 20 lat. 
Niniejsze opracowanie nie ma na celu obalenia owego mitu dobrze ukształtowanego międzywojennego systemu prawa skarbowego, tym bardziej, że jego całościowa i docelowa ocena jest dzisiaj niemożliwa. Wybuch II Wojny Światowej przerwał bowiem bardzo ważny etap zmian wprowadzanych w przepisach ordynacji podatkowej z $1934 \mathrm{r}^{1}{ }^{1}$ oraz niezwykle istotne przekształcenia w strukturach ówczesnych władz skarbowych. Zamysłem tych rozważań jest zbadanie, w jakiego rodzaju przepisach przedwojennego prawa skarbowego kodowane były zwroty niedookreślone (nieostre) i jaką funkcję te specyficzne kategorie prawne pełniły w ówczesnym systemie prawa. Drugim celem artykułu jest analiza stanu badań międzywojennej nauki prawa skarbowego nad jakością leksykalną obowiązujących w tym czasie rozwiązań podatkowo-prawnych. Już w międzywojniu uważano bowiem, że bezwzględnym warunkiem poprawnego stosowania przepisów prawa jest ich zrozumienie, i to przez wszystkie podmioty dokonujące ich interpretacji, a więc nie tylko organy władzy publicznej i sądy, ale także obywateli ${ }^{2}$. Podkreślić należy, że w omawianym okresie nieostre wyrażenia prawne nie były jeszcze przedmiotem odrębnych badań nauki prawa skarbowego ${ }^{3}$. Jednakże jej przedstawiciele wielokrotnie dokonywali krytycznych ocen językowej strony ustawodawstwa skarbowego, intuicyjnie zwracając uwagę bądź na niewłaściwie ujęte pod względem językowym konstrukcje prawne, bądź na zbyt częste i nieuzasadnione kodowanie $\mathrm{w}$ treści norm prawnych sformułowań pod względem językowym niejednoznacznych.

Ze względów metodycznych w niniejszym artykule zastosowano obowiązujący we współczesnej nauce prawa podatkowego podział na zwroty niedookreślone oraz klauzule generalne. Wspólną cechą tych sformułowań jest to, że pierwsze $\mathrm{z}$ nich są doprecyzowywane na etapie stosowania prawa $\mathrm{w}$ oparciu o kryteria i mierniki unormowane w przepisach. Drugi rodzaj omawianych sformułowań, czyli klauzule generalne, na etapie dekodowania wymagają natomiast uwzględnienia wartości i ocen pozaprawnych, a zatem należących do obszaru aksjologicznego ${ }^{4}$.

${ }^{1}$ Ustawa dnia 15 marca 1934 r. Ordynacja podatkowa (Dz.U. RP nr 39, poz. 346 z późn. zm.), dalej jako ordynacja podatkowa.

2 Ordynacja podatkowa. Komentarz. Orzecznictwo - motywy ustawodawcze - okólniki - przepisy zwiqzkowe, oprac. L.S. Margulies, Kraków 1935, s. 4.

${ }^{3}$ Badania takie podejmowali przede wszystkim przedstawiciele nauki prawa prywatnego i handlowego, zob. np. Z. Fenichel, Pojęcie dobrych obyczajów w prawie polskim, „Głos Prawa” 1934, nr 1-3; A. Kraus, F. Zoll, Polska ustawa o zwalczaniu nieuczciwej konkurencji, Poznań 1929.

${ }^{4}$ Zob. szerzej na temat przywołanej klasyfikacji stosowanej w prawie podatkowym: J. Orłowski, Uznanie administracyjne w prawie podatkowym, Gdańsk 2005; J. Leńczuk, Zwroty niedookreślone w procesie stosowania prawa podatkowego, [w:] A. Dybaczewska, E. Juchniewicz, T. Sowiński (red.), Daniny publiczne. Prawo finansowe wobec wyzwań XXI w., Warszawa 2010, s. 131-139; A. Chodun, A. Gomułowicz, A. Skoczylas, Klauzule generalne i zwroty niedookreślone w prawie 
Wybór przeanalizowanych $\mathrm{w}$ artykule ustaw podatkowych został zdeterminowany dwoma rodzajami przesłanek ściśle ze sobą powiązanymi. Pierwszą stanowiła treść aktów prawnych uchwalanych w badanym okresie. Drugą przesłanką były okoliczności ich wprowadzenia do obrotu prawnego oraz czas obowiązywania. $\mathrm{W}$ okresie międzywojennym, a szczególnie w pierwszych latach istnienia II RP, zasady nakładania i poboru podatków dochodowych i majątkowych normowane były licznymi i często zmienianymi aktami prawnymi. $Z$ tych względów na przedmiot analizy wybrano wyłącznie tzw. ustawy podatkowe zunifikowane, czyli takie, które obowiązywały na terytorium całego odrodzonego państwa i których czas obowiązywania obejmował przynajmniej kilka lat. Analizą objęto wyłącznie przepisy materialnego i procesowego prawa skarbowego, pominięto natomiast ustrojowe prawo skarbowe.

II. Prawo podatkowe w okresie międzywojennym rozumiane było jako prawo danin publicznych i stanowiło część składową szerszej gałęzi prawa, czyli prawa skarbowego. Ze względu na ogromne potrzeby fiskalne odrodzonego po 123 latach rozbiorów państwa polskiego, ta właśnie gałąź prawa miała szczególne znaczenie dla funkcjonowania i rozwoju kraju. Na początku lat 20. XX w. ze względu na to, że na obszarze Polski funkcjonowały trzy różne pozaborowe ustroje podatkowe, nie istniał ani uporządkowany system tej gałęzi prawa, ani jednolita polityka podatkowa. Pojęcie polityki podatkowej postrzegane było w ówczesnej literaturze przedmiotu dwojako. Po pierwsze, jako kompleks norm, których powinien przestrzegać system podatkowy. Po drugie, jako zbiór zasad, przyjętych w danym kraju, implementowanych do systemu podatkowego ${ }^{5}$. Podkreślić należy, że dla przedstawicieli nauki prawa skarbowego większym problemem był brak jasnej koncepcji w zakresie prowadzenia spójnej polityki podatkowej aniżeli brak jednolitego systemu podatkowego. Spójny system podatkowy powinien był być bowiem, w ich mniemaniu, efektem racjonalnej myśli politycznej ${ }^{6}$. W pierwszych latach okresu międzywojennego przemyślane i dalekosiężne reformy prawa skarbowego hamowało wiele czynników, do których należał przede wszystkim

podatkowym i administracyjnymi. Wybrane zagadnienia teoretyczne i orzecznicze, Warszawa 2013; A. Hanusz, Klauzule generalne w ordynacji podatkowej, „Państwo i Prawo” 2016, nr 8, s. 3-17; M. Münnich, Zwroty niedookreślone i klauzule generalne w prawie podatkowym. Instrument ochrony praw podatnika czy fundament luzu decyzyjnego organów podatkowych?, [w:] E. Wójcikowska (red.), Jednostka wobec władczej ingerencji administracji publicznej, t. 2, Częstochowa 2013, s. 146-156, eadem, Nieostre zwroty ocenne w polskim prawie podatkowym, Lublin 2017, s. 30-45.

5 J. Lubowicki, Polityka podatkowa Polski, Poznań 1927, s. 142.

${ }^{6}$ Zob. J. Lubowicki, Zasady reformy podatkowej, Warszawa 1928, s. 11. Problem jasnej koncepcji w zakresie polityki podatkowej nie jest obcy także dzisiejszemu prawodawcy, który jednak konstruuje normy prawne w nieporównywalnie korzystniejszych warunkach politycznych (krajowych i zagranicznych) i ekonomicznych. 
wspomniany brak jednolitości ustrojowej państwa, poczynając od administracji publicznej poprzez organizację sądownictwa, na kwestii podziału terytorialnego kończąc. Proces szybkiej integracji przepisów prawa skarbowego utrudniała bardzo trudna sytuacja ekonomiczna państwa, wysoka inflacja, brak narodowej waluty i związany z tym brak jednolitego systemu bankowego ${ }^{7}$. Mimo tych trudnych uwarunkowań gospodarczych i politycznych budowę systemu skarbowego rozpoczęto jeszcze $\mathrm{w}$ trakcie działań wojennych w 1920 r. od procesu ujednolicania ustaw podatkowych stanowiących podstawę poboru najważniejszych pod względem fiskalnym danin państwowych ${ }^{8}$. Do wstępnej unifikacji niektórych ustaw podatkowych doszło w latach 1920-1923, kiedy to ujednolicone zostało ustawodawstwo z zakresu podatku dochodowego i majątkowego ${ }^{9}$ oraz podatku od spadków i darowizn ${ }^{10}$. Podatek przemysłowy został natomiast ostatecznie zunifikowany dopiero w 1925 r. $^{11}$, a opłaty stemplowe normowało ustawodawstwo państw zaborczych aż po rok $1927^{12}$. W kolejnych latach, począwszy od końca 1933 aż do roku 1939, stopniowo wprowadzano zmiany w obowiązujących ustawach i uchwalano nowe akty prawne, konstruując względnie jednolity rodzimy

7 Zob. szerzej: E. Taylor, Prawo skarbowe, „Ruch Prawniczy, Ekonomiczny i Socjologiczny” 1921, r. 1 s. 352-354; por. R. Mastalski, Wymiar podatków w Polsce w latach 1918-1934, „Acta Universitatis Wratislaviensis Przegląd Prawa i Administracji” 1976, t. VII, s. 100-101.

${ }^{8}$ Całościowy wykaz wszystkich ustaw podatkowych obowiązujących w okresie międzywojennym, zob. G.K. Walkowski, System polskiego prawa podatkowego w praktyce. Wybrane zagadnienia, t. VII Źródła prawa podatkowego. Część IV Podatki w dwudziestoleciu międzywojennym (1918-1939), Bydgoszcz 2013, s. 303-446.

${ }^{9}$ Ustawa normująca te dwa rodzaje danin była sukcesywnie wprowadzana w życie w poszczególnych rejonach kraju. Najwcześniej, bo od 1 stycznia 1920 r., jej postanowienia weszły w życie na terenach byłego zaboru rosyjskiego, a następnie, od 1 stycznia 1921 r. - na terenach byłej dzielnicy austriacko-węgierskiej; najpóźniej, bo od 1 stycznia 1924 r., na terenach byłej dzielnicy pruskiej. Zob. ustawa z dnia 16 lipca 1920 r. o podatku dochodowym i podatku majątkowym (Dz.U. RP nr 82, poz. 498 z późn. zm.), dalej jako: ustawa o podatku dochodowym i podatku majątkowym z $1920 \mathrm{r}$. Od początku lat 20. planowano także szerszą reformę poszczególnych podatków głównie bezpośrednich, gdyż w poszczególnych dzielnicach były one inaczej wymierzane i miały inny charakter. Zob. E. Taylor, Prawo skarbowe..., s. 357-358. J. Kulicki, Rozwój podatku dochodowego w Polsce, „Analizy BAS” 2011, nr 6, s. 6, http://orka.sejm.gov.pl/wydbas.nsf/0/3B37ACA7920E9175C12578 B10044422A/\$File/Analiza_\%20BAS_2011_50.pdf [dostęp: 02.01.2017].

10 Zob. ustawa z dnia 29 maja 1920 r. w przedmiocie zmiany przepisów o opodatkowaniu spadków i darowizn (Dz.U. RP nr 49, poz. 299), dalej jako: ustawa o podatku od spadków i darowizn z 1920 r. Zob. J. Serwacki, Opodatkowanie nabycia spadków w Polsce międzywojennej, „Finanse” 1981, nr 4, s. 46-52.

${ }_{11}$ Zob. ustawa $\mathrm{z}$ dnia 15 lipca 1925 roku ustawa o państwowym podatku przemysłowym (Dz.U. RP nr 79, poz. 550 z późn. zm.), dalej: ustawa o państwowym podatku przemysłowym.

12 Zob. ustawa z dnia 1 lipca 1926 r. o opłatach stemplowych (Dz.U. RP nr 98, poz. 570), dalej jako: ustawa o opłatach stemplowych. Ustawę zniesiono dopiero po wojnie dekretem z dnia 11 kwietnia 1947 r. Prawo karne skarbowe (Dz.U. RP nr 32, poz. 140). Zob. R. Mastalski, Prawo podatkowe, Warszawa 2004, s. 452. 
system podatkowy, adekwatny do ustroju politycznego oraz poziomu rozwoju gospodarczego ${ }^{13}$. Niezmiernie rozdrobnione ustawodawstwo dotyczące opodatkowania gruntu scalano stopniowo, zbyt wielkie były bowiem nie tylko różnice w rozwoju gospodarczym i ekonomicznym na ziemiach byłych zaborów, ale i zupełnie odmienne doświadczenia i tradycje podatkowe obowiązujące na tych terytoriach ${ }^{14}$. Odrębnym problemem kodyfikacyjnym było ujednolicenie monopoli państwowych, na terenach podległych poszczególnym rozbiorom istniało bowiem odmienne ustawodawstwo w tym zakresie ${ }^{15}$. Przed wojną podatek akcyzowy jako jedyny nigdy nie został $\mathrm{w}$ pełni zunifikowany i jednolicie unormowany. Poszczególne monopole państwowe opodatkowane były na podstawie odrębnych ustaw, do których z kolei wydawano liczne akty wykonawcze. Z uwagi na to, że podatki akcyzowe miały ogromne znaczenie fiskalne, podatnicy je uiszczający, czyli producenci artykułów objętych akcyzą, poddawani byli szczególnym rodzajom kontroli ${ }^{16}$.

Doniosłym osiągnięciem polskiej przedwojennej myśli legislacyjnej była wspomniana wyżej uchwalona w 1934 r. i wielokrotnie nowelizowana ordynacja podatkowa. Normowała ona w sposób całościowy funkcjonujące wcześniej w poszczególnych ustawach podatkowych kwestie z zakresu materialnego, procesowego i karnego prawa podatkowego.

III. Przedstawiciele ówczesnej nauki prawa skarbowego doskonale rozumieli trudną sytuację polityczną i ekonomiczną kraju. Było dla nich oczywiste, że głównym celem podatku jest zasilenie gospodarstwa narodowego i zrównoważenie

13 Wielką bolączką przedwojennej skarbowości polskiej był brak ustalonej klasyfikacji podatków i opłat na poziomie doktrynalnym. Brak ten odzwierciedlał się niestety w praktyce legislacyjnej. Zasadniczą przyczyną takiego stanu rzeczy był brak rodzimych, zakorzenionych historycznie tradycji podatkowych. W okresie międzywojennym ustawodawca uchwalając kolejne podatki czerpał z wzorców i doświadczeń rosyjskich, pruskich lub austriackich. W rezultacie nie istniały w czystej postaci podatki dochodowe, bezpośrednie czy obrotowe. Szerzej zob. S. Grabiński, Glosa do wyroku NTA z dnia 10 listopada 1933 r., l. 5908/30, „Orzecznictwo Sądów Najwyższych w sprawach podatkowych i administracyjnych” 1934, r. III, poz. 661, s. 268-271; por. R. Mastalski, Wymiar podatków w Polsce w latach 1918-1934..., s. 89-90, 96-110 i literatura tam przywołana oraz idem, Prawo podatkowe..., s. 326-327; R. Langrod, Fikcje skarbowe i fikcje fiskalne w świetle prawa gospodarczego. Refleksje i wnioski z praktyki teorii, Warszawa 1935, s. 9.

${ }^{14}$ Niezależnie od istniejących różnic były to podatki kazuistyczne oparte we wszystkich trzech zaborach na kontyngentach, a w zaborach pruskim i austriackim jeszcze dodatkowo na katastrze gruntu, zob. R. Mastalski, Wymiar podatków w Polsce w latach 1918-1934 ..., s. 91-94

${ }^{15}$ Szerzej zob. D. Mączyński, O akcyzie w Polsce w latach 1918-1939, „Czasopismo Prawno-Historyczne" 2005, t. LVII, z. 1, s. 283-297.

${ }_{16}$ Szerzej o poszczególnych rodzajach podatków akcyzowych zob. D. Mączyński, O akcyzie w Polsce w latach 1918-1939..., s. 286-295. Dodać należy, że ustawy normujące akcyzy miały niezmiernie hermetyczny i kazuistyczny charakter, nie zawierały zwrotów nieostrych pozwalających na uznaniowość i luz interpretacyjny władzom skarbowym. 
budżetu ${ }^{17}$. Jednakże bardzo ostro krytykowali praktykę legislacyjną odrzucającą podstawowe, obowiązujące w państwach zachodniej Europy od wielu lat, zasady naukowo-skarbowe, na rzecz destrukcyjnego w ich opinii fiskalizmu. Według reprezentantów nauki prawa skarbowego najlepszym rozwiązaniem ówczesnych problemów systemu podatkowego, a właściwie jego braku, było stworzenie przemyślanej koncepcji poszczególnych rodzajów podatków, a następnie jej odzwierciedlenie $\mathrm{w}$ treści poprawnie sformułowanych przepisów. Tymczasem zdecydowana większość ustaw podatkowych była niewłaściwie przygotowywana już na etapie ich projektów ${ }^{18}$. Ustawy te, nawet jak na ówczesne czasy, były archaiczne, cechowała je bowiem nadmierna drobiazgowość przepisów podatkowych ${ }^{19}$. Destrukcyjny wpływ na proces stanowienia prawa podatkowego, ale także na jego wykonywanie, miał typowy w międzywojniu lobbing niektórych grup społecznych, między innymi właścicieli ziemskich oraz tzw. „przemysłowców”. Środowiska te z uwagi na okoliczności polityczno-społeczne miały znaczne możliwości oddziaływania na ówczesne władze ustawodawcze tak, aby przy konstruowaniu aktów prawa skarbowego zabezpieczyć własne interesy finansowe. Działo się to niejednokrotnie kosztem budżetu państwa. Inną przyczyną złego stanu prawa skarbowego było, szczególnie krytykowane w pierwszej połowie dwudziestolecia międzywojennego, zjawisko określane mianem ,doktryneryzmu reformatorskiego". Rozumiano przez nie nadmierny i nieracjonalny pośpiech w zmienianiu prawa podatkowego oraz wykorzystywanie podatków jako narzędzi w doraźnej polityce społecznej, a nie dalekowzrocznej polityce skarbowej ${ }^{20}$. Zbyt duża zmienność przepisów, związana z wykorzystywaniem podatków jako instrumentów polityki społecznej, nie przynosiła ani korzyści politycznych, ani fiskalnych ${ }^{21}$.

${ }^{17}$ E. Taylor, Prawo skarbowe..., s. 361; J. Lubowicki, Zasady reformy podatkowe..., s. 12; A. Krzyżanowski, Przedmowa, [w:] E. Stein, A. Thaler (oprac.), Kodeks ustaw podatkowych z orzecznictwem, rozporządzeniami wykonawczemi i przepisami zwiąkowymi, Kraków 1935, s. VII-X.

${ }^{18} \mathrm{Na}$ taki stan rzeczy składało się kilka przyczyn. Po pierwsze na początku lat 20. ustawy podatkowe konstruowane były w oparciu o wzorce ustaw podatkowych obowiązujących w dawnym zaborze rosyjskim. $Z$ niejasnych względów jako wzorce ustawowe przyjęto zostały ustawy podatkowe obowiązujące w zaborze rosyjskim, choć np. najnowocześniejszy był podatek dochodowy w dzielnicy pruskiej.

19 Przykładem takiej prymitywnej zdaniem J. Lubowickiego ustawy była ustawa z dnia 15 czerwca 1923 r., w przedmiocie wyrównywania podatków gruntowych tudzież niektórych podatków budynkowych (Dz.U. RP nr 65, poz. 505 z późn. zm.), zob. J. Lubowicki, Polityka podatkowa Polski..., s. 136138, s. 154; idem, Zasady reformy podatkowej..., s. 12. Zdecydowanie najnowocześniejszy był podatek dochodowy obowiązujący w dawnej dzielnicy pruskiej, jednakże początkowo ustawodawca nie sięgnął do tego wzorca. Uczyniono to w późniejszym okresie, por. E. Taylor, Prawo skarbowe..., s. 357.

${ }^{20}$ Zob. J. Lubowicki, Polityka podatkowa Polski..., s. 136-137.

${ }^{21}$ Ibidem, s. 10-12; E. Taylor, Prawo skarbowe..., s. 353. 
Kolejnym problemem, bardzo często podnoszonym w przedwojennej literaturze, a mającym znaczny wpływ na jakość wykonywania prawa skarbowego, była kwestia leksykalnej strony ustaw podatkowych. Przedstawiciele doktryny prawa skarbowego niejednokrotnie podnosili pod adresem ustawodawcy zarzut nieprawidłowego formułowania treści przepisów podatkowych, w tym nadużywania sformułowań niejasnych, niejednoznacznych, możliwych do rozmaitego interpretowania na etapie stosowania przepisów przez wymiarowe władze skarbowe ${ }^{22}$.

IV. Najczęściej zwroty niedookreślone kodowane były w ustawach podatkowych normujących poszczególne rodzaje podatków, w tym najważniejsze w okresie międzywojennym: podatek dochodowy i majątkowy. Początkowo obydwa rodzaje danin, zarówno w odniesieniu do osób fizycznych, jak i prawnych normowała jedna ustawa z 1920 r., ${ }^{23}$ która w kolejnych latach (1923 i 1925), w wyniku wielkich nowelizacji ulegała znaczącym zmianom ${ }^{24}$. Przede wszystkim z jej przepisów wyłączone zostały postanowienia regulujące podatek majątkowy ${ }^{25}$. Zwroty niedookreślone znalazły zastosowanie nie tylko w treści samych konkretnych ustaw, ale także w wydanych do nich przez ministra skarbu rozporządzeniach wykonawczych.

W ustawie o podatku dochodowym i podatku majątkowym z 1920 r. niejasne sformułowania znajdowały się $\mathrm{w}$ przepisach normujących przesłanki

${ }^{22}$ Uwagi takie podnosili między innymi: J. Lubowicki, Polityka podatkowa Polski..., s. 10-12; Ordynacja podatkowa. Komentarz..., s. 4; W. Runcewicz, Ordynacja podatkowa. Szkic systemu Ordynacji podatkowej, ustawa, rozporządzenia wykonawcze. Komentarz, Warszawa 1935, s. 5.

${ }_{23}$ Przedmiotem tej ustawy był każdy rodzaj dochodów, z wyjątkiem źródeł przychodów enumeratywnie wymienionych. Opodatkowaniu podlegały więc dochody z każdego rodzaju aktywności zawodowej podatnika, prowadzenia przedsiębiorstwa handlowego, przemysłowego, ale również gospodarstwa rolnego (w tym przypadku ustawodawca różnicował zasady ustalania dochodu w zależności od wielkości i miejsca położenia gospodarstwa) i leśnego, aktywności inwestycyjnej oraz z wszelkiego innego rodzaju źródeł przychodów. Był to więc podatek jednolity tak od strony podmiotowej (obowiązek podatkowy ciążył na każdym podmiocie osiągającym dochód ze źródeł określonych w ustawie, bez względu na jego formę prawną), jak i przedmiotowej, obejmował bowiem dochody praktycznie z każdego źródła, powyżej kwoty wolnej od podatku. Zob. J. Kulicki, Rozwój podatku dochodowego w Polsce..., s. 7.

${ }^{24}$ Zob. ustawa z dnia 9 marca 1923 r. w przedmiocie zmiany w przepisach o państwowym podatku dochodowym, obowiązującym na zasadzie ustawy z dnia 4 kwietnia 1922 r. i ustawy z dnia 16 lipca 1920 r. (t.j. Dz.U. RP z 1923 r., nr 77, poz. 607 z późn. zm.), dalej jako: ustawa o państwowym podatku dochodowym z $1923 \mathrm{r}$.

${ }^{25}$ Podatek majątkowy najpierw unormowany został w jednorazowej ustawie, a właściwie uregulowany dopiero w 1929 r. Zob. ustawa z dnia 11 sierpnia 1923 r. o podatku majątkowym (Dz.U. RP nr 94, poz. 746 z późn. zm.) oraz Rozporządzenie Prezydenta Rzeczypospolitej z dnia 3 grudnia 1930 r. o zmianie art. 57 oraz uzupełnieniu art. 67 ustawy o podatku majątkowym (Dz.U. RP nr 86, poz. 660), zob. T. Lulek, Reforma podatku majątkowego w Polsce, Kraków 1929, Odbitka z „Przeglądu Współczesnego" 1929, nr 84, s. 3-22. 
przyznawania przez komisje szacunkowe tzw. zniżek i zwyżek podatkowych w odniesieniu do obydwu przedmiotowych podatków. Zniżki oraz zwyżki podatkowe były charakterystyczne dla przedwojennego i powojennego ustawodawstwa podatkowego. We współczesnym polskim systemie prawa podatkowego nie występują. Podkreślić należy, że przed wojną podatki nakładane były wyłącznie w drodze wymiaru dokonywanego w ramach prowadzonego postępowania podatkowego przez uprawnione do tego organy podatkowe oraz funkcjonujące przy nich tzw. komisje szacunkowe ${ }^{26}$. Ówczesne przepisy pozwalały szczególnie komisjom szacunkowym na swobodne kształtowanie ostatecznej wysokości podatku dochodowego lub majątkowego. Ustalenie kwoty np. podatku dochodowego od osób fizycznych uzależnione było od szeregu ustawowo enumeratywnie wyliczonych przesłanek, wśród których najważniejszymi były: kwota osiągniętego dochodu oraz przynależność dochodu do właściwej klasy miejscowości (od I do IV) ${ }^{27}$. Dodatkowo ostateczny poziom dochodu mógł być kształtowany przez dochód otrzymany w postaci tantiem otrzymywanych z różnych instytucji i przedsiębiorstw bądź też np. wysokość wakujących spadków ${ }^{28}$.

Zgodnie z treścią omawianej ustawy w przypadku osób fizycznych znaczny wpływ na wysokość podatku miała sytuacja rodzinna podatnika. W przypadku osób nieposiadających rodziny istniała bowiem możliwość zastosowania zwyżki

${ }^{26}$ Komisje szacunkowe funkcjonowały w okresie międzywojennym przy obydwóch instancjach władz skarbowych, czyli urzędach i izbach skarbowych. W gremiach tych zasiadały osoby reprezentujące tzw. czynnik społeczny. Komisje szacunkowe wprowadzono do polskiej administracji skarbowej na wzór tego typu komisji funkcjonujących w zaborze pruskim w związku $\mathrm{z}$ ustalaniem podatku dochodowego. Problematyka komisji szacunkowych jest stosunkowo dokładnie opisana w literaturze przedmiotu zob. m.in.: A. Alland, Uprawnienia Komisy Szacunkowych do podatku dochodowego w zakresie udzielania ulg $i$ samodzielnego rozstrzygania odwołań, „Czasopismo Skarbowe. Miesięcznik poświęcony teorii i praktyce skarbowości oraz sprawom zawodowym urzędników skarbowych” 1927, nr 8, s. 3-7. Zob. także krytyczną opinię na temat komisji szacunkowych B.O., Na marginesie projektu ordynacji podatkowej, „Przegląd Gospodarczy" 1934, nr 4, s. 119-120 oraz przegląd opinii na temat komisji szacunkowych innych przedstawicieli przedwojennej doktryny prawa podatkowego, min.: B. Markowskiego, J. Weinfelda, [w:] A. Szwed-Szczygieł, Udziat komisji szacunkowych $w$ procesie wymiaru podatku $w$ Drugiej Rzeczypospolitej do 1934 roku, s. 89-106, online: http://www.zdziejowprawa.pl/flash/t6s89.pdf [dostęp: 10.07.2018]; Sprawozdania oraz zalecenia Komisji Doradców Finansowych pod przewodnictwem Prof. E.W. Kemmerera. Budżet, rachunkowość państwowa, podatki, Nakładem Ministra Skarbu, Kraków 1926, s. 99-104.

27 Zob. art. 23 ustawy o podatku dochodowym i podatku majątkowym z 1920 r.

${ }^{28}$ Zob. art. 23 i 24 ustawy o podatku dochodowym i podatku majątkowym z 1920 r. Celem opodatkowania spadków wakujących było utrzymanie ciągłości opodatkowania danego czynnego źródła przychodu np. przedsiębiorstwa, zob. wyrok Najwyższego Trybunału Administracyjnego (dalej jako: NTA) z dnia 30 listopada 1933 r., 1. 5502/30, „Orzecznictwo Sądów Najwyższych w sprawach podatkowych i administracyjnych” 1934 , r. III, poz. 556, s. 69-70. 
podatku poprzez procentowe podniesienie jego kwoty ${ }^{29}$. Natomiast wobec podatników mających małżonka lub małżonka i dzieci komisje szacunkowe dokonywały zniżek podatku ${ }^{30}$. Udzielanie tego typu preferencyjnych rozwiązań odbywało się przy uwzględnieniu dwóch przesłanek. Pierwszą była sytuacja rodzinna płatnika, określana poprzez liczbę członków rodziny ${ }^{31}$, drugą stanowiło wystąpienie osłabienia tzw. ,siły podatkowej płatnika” na skutek zaistnienia „nadzwyczajnych okoliczności”. Zgodnie z ustawą owe „nadzwyczajne okoliczności” mogły być w obliczaniu podatku uwzględniane przez komisje szacunkowe z urzędu lub na prośbę zainteresowanego płatnika ${ }^{32}$. Co istotne, obydwa rodzaje przesłanek mogły wystąpić łącznie ${ }^{33}$. Z uwagi na obniżenie siły podatkowej płatnika mogła również nastąpić zniżka podatku majątkowego ${ }^{34}$.

Użyte w przywołanych przepisach kluczowe określenia, takie jak „nadzwyczajne okoliczności” oraz „siła podatkowa płatnika”, według dzisiejszego stanu badań zakwalifikować należy do kategorii zwrotów niedookreślonych, gdyż ich zakres znaczeniowy w sposób celowy nie był w ustawie w żaden sposób doprecyzowany. Przedwojenne organy wykonujące prawo dokonując ich interpretacji stosowały zasady wykładni językowej i np. zwrot „,nadzwyczajne okoliczności” wyjaśniany był bardzo ogólnie jako zdarzenia wywołane przez vis maior, na które nie miał wpływu płatnik i których nie mógł ani przewidzieć, ani powstrzymać. O subiektywnym charakterze obydwu zastosowanych w ustawie określeń zdaje się świadczyć redakcja przepisów omawianej ustawy. Z ich treści wynika bowiem, że sytuacje związane z zaistnieniem owych ,nadzwyczajnych okoliczności” obniżających ,siłę podatkową płatnika” mógł podnosić we wniosku do władz

${ }^{29}$ Podatnik nie miał żadnych możliwości powstrzymania komisji szacunkowych przed dokonaniem zwyżki podatku. Nie przysługiwały mu też żadne środki zaskarżenia tego typu decyzji; zob. art. 25 ustawy o ustawy o podatku dochodowym i podatku majątkowym z $1920 \mathrm{r}$. W języku potocznym tego typu zawyżenie podatku określane było jako „bykowe”. Na ogół płacili je bowiem uzyskujący dochody lub posiadający majątek nieżonaci mężczyźni, zob. E. Taylor, Prawo skarbowe..., s. 357.

${ }^{30} \mathrm{~W}$ orzecznictwie NTA podkreślano, że podatnik zobowiązany był do wyczerpującego przedstawienia dokumentów potwierdzających faktyczny stan rodziny uprawniający do skorzystania z tego rodzaju podatkowej preferencji prorodzinnej, zob. np.: wyrok NTA z dnia 16 stycznia 1935 r., 1. rej. 122/33, „Orzecznictwo Sądów Najwyższych w sprawach podatkowych i administracyjnych” 1935, r. IV, poz. 1045, s. 228-229; wyrok NTA z dnia 9 października 1935 r., 1. rej., 926/33 „Orzecznictwo Sądów Najwyższych w sprawach podatkowych i administracyjnych” 1937, r. VI, poz. 1822, s. $444-445$.

${ }^{31}$ Zob. art. 26 akapit pierwszy i art. 27 ustawy o podatku dochodowym i podatku majątkowym z $1920 \mathrm{r}$.

${ }^{32}$ Zob. art. 28 akapit pierwszy ustawy o podatku dochodowym i podatku majątkowym z $1920 \mathrm{r}$.

${ }_{33}$ Zob. art. 28 akapit drugi ustawy o podatku dochodowym i podatku majątkowym z $1920 \mathrm{r}$.

${ }^{34}$ Zob. art. 133 akapit drugi ustawy o podatku dochodowym i podatku majątkowym z $1920 \mathrm{r}$. 
skarbowych zarówno sam płatnik, jak i mogły zostać one stwierdzone z urzędu przez komisje szacunkowe.

Najwidoczniej jednak brak jakichkolwiek ustawowo wskazanych kryteriów pozwalających na dookreślenie niejasno sformułowanych zwrotów okazał się rozwiązaniem niekorzystnym. W lipcu 1921 r., czyli ponad rok po wejściu w życie omawianej ustawy, minister skarbu wydał bowiem rozporządzenie, w którym doprecyzował warunki zastosowania omawianych niedookreślonych zwrotów prawnych. Minister skarbu po pierwsze doprecyzował, że owe „nadzwyczajne okoliczności", o których mowa w ustawie o podatku dochodowym i o podatku majątkowym z 1920 r., mogą dotyczyć zarówno samego podatnika, jak i członka jego rodziny. Zarówno tego, który pozostaje na utrzymaniu podatnika, jak i tego, którego majątkiem podatnik rozporządza ${ }^{35}$. Po drugie, minister wskazał przykładowe zdarzenia faktyczne, które mogły być uznane przez komisje szacunkowe za „nadzwyczajne okoliczności”. Zgodnie z przywołanym rozporządzeniem do katalogu tego typu zdarzeń należały następujące sytuacje:

- powołanie do służby wojskowej,

- nadmierne ciężary z powodu obarczenia zbyt liczną rodziną,

- wyjątkowy obowiązek wspomagania niezamożnych członków rodziny,

- długotrwała choroba,

- zadłużenie i inne szczególnie krytyczne okoliczności,

- wydarzenia żywiołowe: pożar, powódź, gradobicie,

- klęska z powodu działań wojennych,

- itp. okoliczności, których skutków nie uwzględniono przy ustalaniu wysokości dochodu ${ }^{36}$.

Zgodnie z intencją ministra skarbu powyższa lista zdarzeń, które mogły wypełnić zakres znaczeniowy sformułowania „nadzwyczajne okoliczności”, była otwarta. Katalog został pod względem językowym sformułowany na tyle niejasno, że poza oczywistym zdarzeniem, takim jak powołanie do służby wojskowej, każdy z pozostałych punktów wykazu otwierał komisjom szacunkowym in concreto drogę do zastosowania swobodnego uznania w zakresie interpretacji tego, czy np. dana choroba może być potraktowana jako długotrwała czy też nie, lub czy dane zdarzenie można potraktować jako gradobicie z uwagi na powstałe szkody, czy raczej nie. Podkreślić należy, że regułą było, iż celem przeprowadzanej w danym

${ }^{35}$ Zob. $\S 48$ zdanie pierwsze rozporządzenia Ministra Skarbu z dnia 14 maja 1921 r. w przedmiocie przepisów wykonawczych do ustawy o państwowym podatku dochodowym i podatku majątkowym (Dz.U. RP nr 48, poz. 298), dalej jako: rozporządzenie Ministra Skarbu w przedmiocie przepisów wykonawczych do ustawy o państwowym podatku dochodowym i podatku majątkowym z $1921 \mathrm{r}$.

${ }^{36}$ Zob. § 48 pkt 3 rozporządzenia Ministra Skarbu w przedmiocie przepisów wykonawczych do ustawy o państwowym podatku dochodowym i podatku majątkowym z $1921 \mathrm{r}$. 
stanie faktycznym wykładni prawa było ustalenie granic znaczenia językowego wyrażeń nieostro sformułowanych w przepisach ${ }^{37}$.

Komisje szacunkowe mogły na mocy odrębnych przepisów omawianej ustawy o podatku dochodowym i majątkowym udzielać jeszcze jednego rodzaju ulg podatkowych, a mianowicie umorzenia części lub całości podatku. Zastosowanie tego typu preferencji podatkowej uzależnione było od pojawienia się jednej z dwóch nieostro sformułowanych przesłanek: „nieszczęśliwych okoliczności” lub „nadzwyczajnych wydarzeń”, których wystąpienie mogło „znacznie osłabić zdolność płatniczą osoby fizycznej”. Tego typu ulga podatkowa mogła być zastosowana przez władze wymiarowe wyłącznie na prośbę podatnika, wniesioną najdalej do końca roku podatkowego. Komisja szacunkowa dokonywała umorzenia odpowiedniej części wymierzonego podatku, o ile uznała, że podatnik takiej ulgi potrzebuje ${ }^{38}$. Ponieważ ustawa nie definiowała i nie egzemplifikowała tego, co poprzez obydwa nieostre określenia należy rozumieć, doprecyzowywało je przywołane wyżej rozporządzenie ministra skarbu w przedmiocie przepisów wykonawczych do ustawy o państwowym podatku dochodowym i podatku majątkowym z $1921 \mathrm{r}$. Zgodnie z jego treścią przyznanie tego rodzaju ulgi miało mieć charakter wyjątkowy, ponieważ komisje szacunkowe mogły z tej prerogatywy skorzystać wyłącznie w stosunku do osób fizycznych i tylko wówczas, gdy ich zdolność płatnicza znacznie osłabła w ciągu roku podatkowego wskutek pojawienia się „nieszczęśliwych okoliczności” lub „nadzwyczajnych wydarzeń”. Ulga mogła objąć jedynie część należnego podatku. Utratę owej zdolności płatniczej podatnik musiał jednak najpierw udowodnić przed organami wymiarowymi. W rozporządzeniu zostały wskazane przykładowe sytuacje, które można było uznać za „nieszczęśliwe okoliczności” lub „nadzwyczajne wydarzenia". W katalogu tym wskazano takie zdarzenia jak: długotrwała choroba, śmierć członka rodziny, wybuch wojny, powódź, grad, pożar i inne wydarzenia żywiołowe ${ }^{39}$. Ponadto w rozporządzeniu rozdzielone zostały bardzo precyzyjnie okoliczności wskazujące na ,utratę źródła dochodu” oraz przesłanki wskazujące na „znaczne obniżenie wydajności źródła dochodu”. I tak utrata źródła dochodu mogła nastąpić w wyniku:

${ }^{37}$ Komisje szacunkowe, zgodnie $\mathrm{z}$ omawianym rozporządzeniem, miały obowiązek rozważyć w każdym poddawanym weryfikacji przypadku, jak dalece utracona została zdolność płatnicza i adekwatnie do ustaleń dokonać zniżki podatkowej, maksymalnie o trzy stopnie procentowe. Uzasadnienie zniżki powinno było być przedstawione $\mathrm{w}$ protokole $\mathrm{z}$ posiedzenia komisji. Zob. $\S 48$ zdanie ostatnie rozporządzenia Ministra Skarbu w przedmiocie przepisów wykonawczych do ustawy o państwowym podatku dochodowym i podatku majątkowym z $1921 \mathrm{r}$.

${ }_{38}$ Zob. art. 83 akapit 2 ustawy o państwowym podatku dochodowym i podatku majątkowym z $1921 \mathrm{r}$.

39 Zob. § 150 akapit 4 rozporządzenia Ministra Skarbu w przedmiocie przepisów wykonawczych do ustawy o państwowym podatku dochodowym i podatku majątkowym z $1921 \mathrm{r}$. 
- utraty lub pozbycia się prawa użytkowania,

- pożaru, zawalenia się lub zburzenia budynku czynszowego,

- zaniechania przedsiębiorstwa handlowego lub przemysłowego,

- utraty kapitału,

- wygaśnięcia prawa do renty,

- utraty prawa do pretensji z powodu licytacji przymusowej lub w postępowaniu konkursowym,

- utraty do pracy z powodu starości lub trwałej choroby,

- itp..$^{40}$

Natomiast „znaczne obniżenie wydajności źródła dochodu” mogło być spowodowane wystąpieniem jednego z następujących zjawisk:

- gorszym urodzajem,

- nieściągalnością tenuty dzierżawnej,

- zmniejszeniem się obrotów w przedsiębiorstwie,

- ograniczeniem ruchu w przedsiębiorstwie,

- zmniejszeniem się lub ubytkiem dywidend od akcji

- itp. ${ }^{41}$

Rzeczywistą sytuację płatnika oraz poziom jego zdolności płatniczej komisje szacunkowe zobowiązane były ustalić indywidualnie dla każdej sytuacji faktycznej z uwzględnieniem ogólnego położenia ekonomicznego podatnika. Przepisy rozporządzenia w sposób kazuistyczny normowały nie tylko sposób obliczenia wysokości kwoty umarzanego podatku ${ }^{42}$, ale także odrębnie regulowały postępowanie w sprawie tego typu ulgi podatkowej ${ }^{43}$.

Inny rodzaj zwrotu niedookreślonego zastosowany został w rozporządzeniu ministra skarbu wydanym w porozumieniu z ministrem spraw wewnętrznych, dotyczącym udzielania ulg podatkowych. W przepisach tego aktu prawnego znalazły się postanowienia na mocy, których minister skarbu mógł odmówić udzielenia ulgi podatkowej z uwagi na to, że zaległości podatkowe powstały wskutek ,,jawnej złej woli płatnika". Minister mógł swoje uprawnienie w tym zakresie przenieść na właściwe izby skarbowe ${ }^{44}$. Interpretacja zastosowanego nieostro sformułowanego zwrotu dokonywana była przez właściwy organ podatkowy na podstawie

40 Zob. § 150 akapit 6 rozporządzenia Ministra Skarbu w przedmiocie przepisów wykonawczych do ustawy o państwowym podatku dochodowym i podatku majątkowym z $1921 \mathrm{r}$.

${ }^{41}$ Zob. $\S 150$ akapit 7 rozporządzenia Ministra Skarbu w przedmiocie przepisów wykonawczych do ustawy o państwowym podatku dochodowym i podatku majątkowym z $1921 \mathrm{r}$.

${ }^{42}$ Zob. art. 150 pkt 8-9 rozporządzenia Ministra Skarbu w przedmiocie przepisów wykonawczych do ustawy o państwowym podatku dochodowym i podatku majątkowym z $1921 \mathrm{r}$.

${ }^{43}$ Zob. § 151 rozporządzenia Ministra Skarbu w przedmiocie przepisów wykonawczych do ustawy o państwowym podatku dochodowym i podatku majątkowym z $1921 \mathrm{r}$.

${ }_{44}$ Zob. $\$ 10$ rozporządzenia Ministra Skarbu z dnia 25 listopada 1933 r. wydane w porozumieniu z Ministrem Spraw Wewnętrznych o ulgach w spłacie zaległości podatkowych Dz.U. RP nr 94, 
przedstawionej przez płatnika dokumentacji. Organy zobowiązane były do dokładnego obiektywnego przedstawienia okoliczności faktycznych, świadczących o złej woli płatnika ${ }^{45}$. Przy tym przepisy w żaden sposób nie precyzowały, jakie zdarzenia i zachowania podatnika mogłyby świadczyć o jego jawnie złej woli. Można domniemywać, że wykazanie złej woli płatnika wiązało się z ustaleniem przez władze skarbowe nieprzestrzegania prawa podatkowego lub jego obejścia.

Wszystkie zwroty niedookreślone użyte w omówionej wyżej ustawie o podatku dochodowym i o podatku majątkowym z 1920 r. oraz wydanym do niej rozporządzeniu, czyli „nadzwyczajne okoliczności”, „siła podatkowa płatnika”, „nieszczęśliwe okoliczności” i „nadzwyczajne wydarzenia” oraz przykładowe katalogi powyższych zdarzeń zawierające kolejne nieostro sformułowane zwroty, znalazły się w dwóch kolejnych znowelizowanych tekstach ustawy o podatku dochodowym z roku 1923 oraz $1925^{46}$, a także w wydanych do nich rozporządzeniach ministra skarbu ${ }^{47}$. Głównym celem zmian wprowadzonych do ustawy o państwowym podatku dochodowym była poprawa drastycznej sytuacji podatników polegającej m.in. na odciążeniu ich z obowiązku składania deklaracji podatkowych w określonych prawem przypadkach oraz na zróżnicowaniu według województwa minimum egzystencjalnego ${ }^{48}$.

Analiza międzywojennego orzecznictwa NTA dotyczącego podatku dochodowego i majątkowego wskazuje, że podatnicy często składali wnioski o przyznanie

poz. 731 w zw. z ustawą z dnia 10 marca 1932 r. o spłacie zaległości podatkowych (Dz.U. RP nr 29, poz. 291).

45 Zob. wyrok NTA z dnia 12 listopada 1936 r., 1. rej. 5824/34, „Orzecznictwo Sądów Najwyższych w sprawach podatkowych i administracyjnych” 1937 , r. VI, poz. 1709, s. 126-127.

46 Zob. art. 29 oraz art. 84 akapit drugi ustawy z dnia 18 kwietnia 1925 r. o państwowym podatku dochodowym (Dz.U. RP nr 58, poz. 410 i 411 z późn. zm.), dalej jako: ustawa o państwowym podatku dochodowym z $1925 \mathrm{r}$. Stopniowa reforma podatku dochodowego wzorowana była na rozwiązaniach angielskich, a jej celem było skonstruowanie na tyle dobrego aktu prawnego, by uwzględniał zasady sprawiedliwości i demokratyczności. Niestety w opinii przedwojennej doktryny kolejne wersje ustawy o podatku dochodowym $\mathrm{z}$ dwóch powodów nie spełniały pokładanych w nim nadziei. Po pierwsze, z uwagi na to, że nowoczesna konstrukcja ustawy nie odpowiadała ówczesnym polskim stosunkom kulturalno-społecznym. Po wtóre, aparat skarbowy nie potrafił sprawnie wykonywać przepisów ustawy, zgodnie z intencją ustawodawcy. Urzędnicy byli do tego nieprzygotowani pod względem merytorycznym. Zob. J. Piełakiewicz Podatek dochodowy i majątkowy w Polsce, ,Ruch Prawniczy, Ekonomiczny i Socjologiczny” 1924, r. 4, s. 6.

47 Zob. § 43 rozporządzenia Ministra Skarbu z dnia 14 września 1934 r. w sprawie wykonania ustawy o państwowym podatku dochodowym (Dz.U. nr 85 poz. 769). Kolejne rozporządzenie w tej sprawie wydane zostało w 1936 r., zob. § 40 oraz rozporządzenia Ministra Skarbu z dnia 27 kwietnia 1936 r. w sprawie wykonania ustawy o państwowym podatku dochodowym (Dz.U. RP nr 40, poz. 301). Wydanie obu rozporządzeń związane było z potrzebą dostosowania aktów wykonawczych do ustawy o państwowym podatku dochodowym w odniesieniu do różnych postanowień, w tym przepisów regulujących przyznawanie ulg podatkowych przez władze wymiarowe.

48 J. Piełakiewicz Podatek dochodowy i majątkowy w Polsce..., s. 7. 
ulg w postaci umorzenia części lub całości wymierzonego podatku, powołując się przy tym na różne przyczyny obniżające ich zdolność podatkową. NTA w jednym z orzeczeń jednoznacznie wskazał, że skuteczność tego typu wniosków w znacznej mierze zależała od wiarygodności przedstawionych przez podatnika dokumentów udowadniających owe znaczne obniżenie wydajności źródła dochodów ${ }^{49}$.

Przykładem innej regulacji zawierającej zwroty niedookreślone była ustawa o podatku przemysłowym z 1923 r. $^{50}$ znowelizowana w 1925 r., w ramach której unormowany był pierwszy powojenny podatek obrotowy (tj. po I wojnie światowej $)^{51}$. Zgodnie $\mathrm{z}$ treścią przywołanej ustawy minister skarbu miał prawo do udzielenia ulg podatkowych w postaci: odroczenia, rozłożenia na raty, całkowitego lub częściowego umorzenia zaległości podatkowej, a także darowania skutków niedotrzymania wszelkich terminów przewidzianych w ustawie o podatku przemysłowym. Z tych uprawnień mógł skorzystać w „wyjątkowych wypadkach, zasługujących na szczególne uwzględnienie", gdyby uiszczenie podatku mogło narazić „,egzystencję gospodarczą płatnika”. Wymienione prerogatywy w zakresie udzielania ulg podatkowych płatnikom podatku przemysłowego, minister mógł przenieść na izby skarbowe ${ }^{52}$. Omawiane przepisy, w dalszych akapitach, poprzez zastosowanie kolejnych zwrotów niedookreślonych rozbudowywały kompetencje ministra skarbu o dalsze uprawnienia. Zgodnie $\mathrm{z}$ ich treścią minister mógł w porozumieniu z ministrem przemysłu i handlu ze względu na ,potrzeby gospodarcze”:

- zaniżać, względnie zawieszać podatek od transakcji eksportowych co do surowców krajowych w wypadkach, w których pobór tego podatku okazałby się istotna przeszkodą dla rozwoju eksportu,

- udzielać przedsiębiorstwom państwowym eksportującym wyroby własne, względnie organizacjom eksportowym tych przedsiębiorstw, bonifikacji podatku uiszczonego od obrotów,

- zaniżać podatek od obrotów ze sprzedaży na rzecz firm niepłacących podatku przemysłowego ${ }^{53}$.

W przypadku ustawy o podatku przemysłowym ustawodawca ani w powołanej ustawie, ani w wydanym do niej rozporządzeniu w ogóle nie dookreślił znaczenia zastosowanych nieostro sformułowanych zwrotów prawnych, czyli „wyjątko-

49 Zob. wyrok NTA z dnia 30 listopada 1933 r. 1. rej. 4898/30, „Orzecznictwo Sądów Najwyższych w Sprawach Podatkowych i Administracyjnych" 1934, r. III, poz. 527, s. 12-13.

50 Zob. art. 4-5 ustawy z dnia 14 maja 1923 r. w przedmiocie państwowego podatku przemysłowego (Dz.U. RP 1923 nr 58, poz. 412), dalej: ustawa o państwowym podatku przemysłowym z $1923 \mathrm{r}$.

51 Zob. art. 4-5 ustawy z dnia 15 lipca 1925 r. o państwowym podatku przemysłowym (Dz.U. RP, nr 79, poz. 550 ze zm.), dalej jako: ustawa o państwowym podatku przemysłowym z $1925 \mathrm{r}$. Ustawa obowiązywała do końca 1938 r., zob. R. Mastalski, Prawo podatkowe..., s. 453.

${ }_{52}$ Zob. art. 94 (dwa pierwsze akapity) ustawy o państwowym podatku przemysłowym z $1925 \mathrm{r}$.

${ }_{53}$ Art. 94 (trzeci akapit) ustawa o państwowym podatku przemysłowym z $1925 \mathrm{r}$. 
wych wypadków, zasługujących na szczególne uwzględnienie”, „egzystencji gospodarczej płatnika” oraz „potrzeb gospodarczych” oraz , istotnej przeszkody” ${ }^{4}$.

$\mathrm{Na}$ temat omawianych przepisów ustawy o podatku przemysłowym wypowiedział się NTA, który uznał, że treść komentowanych przepisów art. 94 akapit 3 jest w pełni uzasadniona i ma przede wszystkim uzasadnienie i znaczenie gospodarcze. Trybunał szczególną rolę przypisał obniżeniu podatku lub zwolnieniu z podatku obrotów podatkowych będących wynikiem transakcji eksportowych. Taki rodzaj preferencji podatkowych mógł bowiem ożywić eksport poprzez umożliwienie obniżenia cen eksportowych surowców krajowych. Przy czym ulgi dotyczyły wyłącznie cen z obrotu, gdyż to one miały z jednej strony widoczny wpływ na kształtowanie się cen konkurencyjnych przy eksporcie, a drugiej mogły stanowić widoczną pomoc w redukcji kosztów handlowych rodzimych przedsiębiorców ${ }^{55}$.

Przepisy ustawy o podatku przemysłowym przyznawały ministrowi skarbu jeszcze jedno uprawnienie: dotyczące uwolnienia od tego podatku (zwolnienia) tych przedsiębiorstw państwowych i komunalnych, których bezpośrednim zadaniem było popieranie celów publicznych, dobroczynnych lub ogólnie użytecznych, jeżeli obrót tych przedsiębiorstw był „stosunkowo nieznaczny” ${ }^{\prime 6}$. W przywołanych przepisach zakodowane zostały nieco inne określenia o otwartym znaczeniu, których treść przypomina współczesne klauzule generalne. Zwroty te odsyłały bowiem do pozaprawnych kryteriów o podłożu aksjologicznym, takim jak względy moralne i społeczne. Drugą równie nieostro sformułowaną przesłanką uzasadniającą zastosowanie omawianej preferencji podatkowej było osiąganie przez dane przedsiębiorstwo „stosunkowo nieznacznych obrotów”.

IV. Wśród przedstawicieli przedwojennej doktryny prawa skarbowego omówione wyżej rozwiązania prawne zawierające zwroty niedookreślone budziły rozbieżne opinie. Większość teoretyków krytykowała obowiązujące wówczas przepisy przede wszystkim z tego powodu, że ich redakcja umożliwiała władzom skarbowym wymierzanie podatków i stosowanie różnego rodzaju preferencji podatkowych wyłącznie w oparciu o uznanie administracyjne. W opinii teoretyków

${ }^{54}$ W przepisach rozporządzenia Ministra Skarbu z dnia 8 sierpnia 1925 r. w celu wykonania ustawy z dnia 15 lipca 1925 r. o państwowym podatku przemysłowym (Dz.U. RP nr 82, poz. 560) w ogóle nie zamieszczono przepisów wykonawczych do art. 94 ustawy o państwowym podatku przemysłowym z 1925 r., normującego zasady udzielania ulg podatkowych.

${ }_{55}$ Zob. wyrok NTA z dnia 10 grudnia 1932 r., 1. rej. 2562/30, 5435/30, „Orzecznictwo Sądów Najwyższych w sprawach podatkowych i administracyjnych” 1932-1933, r. I-II, poz. 344, s. 479-480; wyrok NTA z dnia 28 lutego 1934 r., 1. rej. 3232/33, „Orzecznictwo Sądów Najwyższych w sprawach podatkowych i administracyjnych" 1934 , poz. 706, s. 357-358.

${ }^{56}$ Zob. art. 121 ustawy o państwowym podatku przemysłowym z $1925 \mathrm{r}$. 
prawa skarbowego regulacjom licznych ulg i zwolnień podatkowych nie towarzyszyła żadna jednolita, konsekwentna myśl legislacyjna. Kolejne preferencje podatkowe wprowadzane były bowiem do przepisów skarbowych pod wpływem różnorakich poglądów, z reguły zależnych od doraźnych interesów lub koncepcji różnych środowisk lobbingowych. Skutki tego były bardzo poważne i różnorodne. Po pierwsze, nadmiernie rozbudowany system ulg oparty na nieostrych kryteriach prawnych powodował brak bezwzględnej pewności wymiarów podatkowych. Efektem braku owej pewności prawa podatkowego było z kolei wprowadzenie do stosunków panujących pomiędzy płatnikami a władzami skarbowymi ,atmosfery targów", a ta z kolei nie służyła ani wychowaniu moralności podatkowej płatników, ani sprawności działania władz skarbowych. Zdaniem przedstawicieli doktryny prawa skarbowego ulgi jako instytucje podatkowe winny były wynikać wyłącznie z samej konstrukcji podatku (np. ze względów rodzinnych lub różnego charakteru źródeł dochodowych, degresji itp.) i żadnych innych preferencji podatkowych tego typu, szczególnie o charakterze gospodarczym, system podatkowy nie powinien był zawierać. Różnicę między wymiarem konkretnego podatku a zaplanowanymi wpływami uzasadniać mogły bowiem wyłącznie okoliczności wskazujące na bezwzględną nieściągalność tej daniny ${ }^{57}$.

Krytyczni badacze ówczesnego prawa skarbowego twierdzili ponadto, że ową tak niebezpieczną z punktu widzenia sprawiedliwości podatkowej płaszczyznę uznaniowości, w ramach której dokonywali rozstrzygnięć urzędnicy skarbowi rozbudowują zakodowane $\mathrm{w}$ przepisach niejasno sprecyzowane zwroty stanowiące podstawę udzielania ulg i zwolnień podatkowych. Przyznawanie różnego rodzaju preferencji podatkowych unormowanych zarówno w ustawie o państwowym podatku dochodowym, jak i w ustawie o podatku przemysłowym nie odbywało się bowiem w oparciu o jakichkolwiek obiektywne dane finansowe i ekonomiczne. Interpretacja wszystkich nieostro sformułowanych przesłanek służących ustaleniu tego, czy zaistniały, czy też nie „,nadzwyczajne okoliczności”, ,potrzeby gospodarcze”, „stosunkowo nieznaczne obroty”; czy miał miejsce spadek „siły podatkowej płatnika”, czy wystąpiła ,jawnie zła wola podatnika” przebiegała wyłącznie na podstawie subiektywnych ocen i ustaleń poczynionych przez władze wymiarowe. Rozwiązanie takie, w opinii przedstawicieli nauki, gwarantowało z całą pewnością zupełną dowolność i dużą nierównomierność w rozkładzie ciężaru podatkowego ${ }^{58}$.

Zdaniem innych przedstawicieli doktryny zwalnianie przedsiębiorstw państwowych i komunalnych z podatku przemysłowego było rozwiązaniem naruszającym

${ }^{57}$ Zob. J. Lubowicki, System ulg podatkowych, „Czasopismo Skarbowe” 1927, nr 2, s. 12; idem, Polityka podatkowa Polski..., s. 147; T. Lulek, Przywileje podatkowe..., s. 200-249.

${ }_{58}$ Zob. J. Lubowicki, System ulg podatkowych, „Czasopismo Skarbowe” 1927, nr 2, s. 10-12; idem, Polityka podatkowa Polski..., s. 147. 
nie tylko zasadę sprawiedliwości i równości podatkowej, ale zakłócającym także podstawowe zasady konkurencji w obrocie gospodarczym. $\mathrm{Z}$ tego typu szerokich preferencji podatkowych nie mogły bowiem korzystać przedsiębiorstwa prywatne ${ }^{59}$.

Przedstawiciele przedwojennej doktryny prawa skarbowego nie byli jednak jednomyślni w ocenie obowiązującej polityki podatkowej zezwalającej na liczne preferencje podatkowe oraz stosowanie zwrotów niedookreślonych w przepisach prawa skarbowego. W literaturze przedmiotu można bowiem znaleźć głosy aprobujące udzielanie ulg podatkowych w oparciu o nieostro sformułowane przesłanki, gdyż służyło to zmniejszeniu finalnych obciążeń fiskalnych. W opinii przywołanych autorów zasadniczym celem i uzasadnieniem tego typu rozwiązań prawnych mogła być bowiem ochrona źródeł dochodowych przed ewentualnym przeciążeniem podatkowym, mogącym znacznie osłabić wydajność tych źródeł. Innymi słowy ulgi mogły stanowić narzędzie służące temu, aby podatek sprowadzić do takiego poziomu, by odpowiadał on możności płatniczej kontrybuentów, czyli zdolności podatkowej płatników ${ }^{60}$. Wspomnieć należy również, że w okresie międzywojennym byli i tacy przedstawiciele doktryny, którzy akceptowali potrzebę stosowania zwrotów nieostro sformułowanych jako przesłanek udzielania preferencji podatkowych z uwagi na konieczność uelastycznienia niezwykle skostniałych i hermetycznych przepisów podatkowych. W szczególny sposób aprobowane były takie nieostre sformułowania, które otwierały system prawa skarbowego na oceny pozanormatywne i kryteria o charakterze rodzinnym lub gospodarczym. Przedstawiciele doktryny uznawali tego rodzaju kategorie prawne za jak najbardziej pożądany instrument prawnopodatkowy. Jednakże wskazywali, że są to rozwiązania wymagające przemyślanej polityki podatkowej. Nie mogły być one wykorzystywane w sposób doraźny, powiązany z działaniami politycznymi, ani też naruszać zasady równomierności ciężaru podatkowego ${ }^{61}$.

59 Zob.: T. Lulek, Przywileje podatkowe przedsiębiorstw publicznych, Kraków 1928, s. 200-249.

${ }^{60}$ A. Alland, Uprawnienia Komisy Szacunkowych ..., s. 3. Podobnie uważał R. Rybarski, który dzielił ulgi na ogólne i specjalne, i przypisywał poszczególnym ich typom różne znaczenie. Po pierwsze, ulgi podatkowe (np. w postaci niższych stawek podatkowych) były konsekwencją zasady sprawiedliwości podatkowej, w myśl której jednostki ekonomicznie słabsze należało opodatkować niższym podatkiem. Drugi rodzaj ulg skutkował zupełnym uwolnieniem z podatku. Udzielenie tego typu preferencji powinno było wiązać się z polityką ekonomiczną państwa i specjalnym traktowaniem fiskalnym niektórych gałęzi wytwórczości i obrotu. Ten drugi typ ulg autor określił też mianem subwencji państwa i podnosił, że powinny mieć one bardzo ograniczony charakter, zob. tegoż, Glosa do wyroku NTA z dnia 4 grudnia 1936 r., L. REJ. 6530/33, „Orzecznictwo Sądów Najwyższych w Sprawach Podatkowych i Administracyjnych” 1937, r. VI, poz. 1767, s. 275-280.

${ }^{61}$ Szerzej zob. J. Lubowicki, Polityka podatkowa Polski..., s. 148-150; R. Rybarski, Glosa do wyroku NTA z dnia 4 grudnia 1936 r., L. REJ. 6530/33, „Orzecznictwo Sądów Najwyższych w Sprawach Podatkowych i Administracyjnych” 1937, r. VI, poz. 1767, s. 282. 
Przedwojenni juryści, podobnie jak współcześni, oceniali bardzo krytycznie stronę leksykalną ustaw podatkowych. W literaturze przedmiotu można znaleźć niezwykle interesujący dla dzisiejszego badacza i obserwatora prawa podatkowego pogląd, że w odniesieniu do ustaw podatkowych, z uwagi na ich niezwykle skomplikowaną szatę gramatyczną, mniej rygorystycznie powinna być przestrzegana zasada ignorantia iuris nocet. Zdaniem badaczy prawa skarbowego w okresie dwudziestolecia międzywojennego, język ustaw podatkowych był bowiem tak niezmiernie złożony, pełny trudnych różniczkowań i skomplikowanego cieniowania, że przeciętny obywatel nie był w stanie jednoznacznie zrozumieć ich treści. Ponadto do ustaw podatkowych ministerstwo skarbu publikowało liczne wyjaśnienia. Naganne, w opinii doktryny, było to, że znajomość owych wyjaśnień, mających formę aktów podustawowych, była ważniejsza z punktu widzenia ochrony praw płatnika aniżeli znajomość głównej ustawy. Do podatku przemysłowego wydano na przykład 250 okólników ${ }^{62}$. W rezultacie problemy interpretacyjne dotyczące znaczenia całych przepisów podatkowych czy też poszczególnych sformułowań rozjaśniały właśnie okólniki ministra skarbu, bez których prawo podatkowe było niezrozumiałe. Niestety, w opinii doktryny, zdarzało się, że owe okólniki były sprzeczne z duchem, a często i tekstem ustaw. Bez wątpienia owa nieznajomość przepisów wynikająca $\mathrm{z}$ ich niezrozumienia była $\mathrm{w}$ okresie międzywojennym największym zagrożeniem nie tylko dla samych podatników ${ }^{63}$, ale również dla prawników, którzy nie rozumiejąc prawa nie mogli skutecznie chronić indywidualnych interesów ${ }^{64}$, jak również dla przedstawicieli doktryny, polityków oraz osób biorących udział w pracach legislacyjnych.

${ }^{62}$ Znacznie lepszym pod względem legislacyjnym aktem prawnym była ustawa o opłatach stemplowych, ale tak trudnym, że wydano do niej tyle wyjaśnień w ciągu jednego roku, że złożyły się one na niemałą książkę, zob. J. Lubowicki, Zasady reformy podatkowej..., s. 72; B. Markowski, recenzja książki R. Langroda i A. Franza, Państwowy podatek dochodowy. Podręcznik, Warszawa 1932, „Ruch Prawniczy, Ekonomiczny i Socjologiczny” 1932, r. 12, z. 3, s. 941.

${ }^{63}$ Ze sprawozdania posła Mościckiego z 27 lutego 1923 r. w Sejmie w odniesieniu do ustawy o podatku dochodowym z 1920 r.: „Do płacenia podatków zostały powołane całe rzesze płatników będących w znacznej części półanalfabetami, którzy muszą wypełniać formularze zeznań nie rozumiejąc treści zawartych w nich pojęć. 95\% podatników jest niezdolnych do wykonywania nałożonych nań obowiązków płatników podatku dochodowego. Co oznacza, że cały ciężar wymiaru podatku spada na władze skarbowe. Podatek dochodowy w konsekwencji zatraca swój charakter, bo władze skarbowe nie posiadają stosownych danych do dokonywania jego wymiaru zgodnie z zasadami opodatkowania czystego dochodu. Ponadto władze są źle zorganizowane, nieudolne, niewyszkolone. Muszą one nakładać podatek według danych zupełnie zewnętrznych, cech przypadkowych, co prowadzi do iluzji sprawiedliwości podatkowej. Na podstawach zupełnego widzimisię władze skarbowe stosują dla każdego powiatu odrębne metody wymiaru podatku(...) jest to krzywdzące i niesprawiedliwe...", cyt. za: J. Piełakiewicz Podatek dochodowy i majątkowy w Polsce, „Ruch Prawniczy, Ekonomiczny i Socjologiczny” 1924, r. 4, s. 7.

${ }^{64}$ Ordynacja podatkowa. Komentarz. Orzecznictwo - motywy ustawodawcze - okólniki przepisy zwiąkowe, oprac. L.S. Margulies, Kraków 1935, s. 4. 
V. Przeprowadzona analiza wybranych przedwojennych przepisów normujących najważniejsze ze względów fiskalnych rodzaje podatków obowiązujących w latach 1919-1939 oraz ówczesnej literatury przedmiotu, a także nielicznego wówczas orzecznictwa podatkowego NTA prowadzi do następujących konkluzji. Po pierwsze, przedwojenny ustawodawca chętnie kodował w treści przepisów podatkowych określenia nieostre, otwarte na szeroką interpretację w oparciu kryteria pozanormatywne. Po wtóre, zwroty tego rodzaju wprowadzano z reguły do treści przepisów normujących przyznawanie przez władze wymiarowe różnego typu preferencji podatkowych. Po trzecie, w przedwojennych ustawach podatkowych widoczny jest brak jednolitej koncepcji w zakresie posługiwania się owymi zwrotami nieostrymi w kontekście ulg i zwolnień podatkowych. O ile bowiem w przypadku podatku dochodowego i majątkowego (od osób fizycznych i prawnych) widoczna była tendencja do zawężania pola interpretacji sformułowań nieostrych, to już takiej intencji nie można odnaleźć w treści przepisów normujących podatek przemysłowy.

Wszystkie wybrane i omówione zwroty nieostre zakodowane w przedwojennym ustawodawstwie podatkowym miały wspólny mianownik. Przedwojenny legislator ewidentnie wykorzystywał tego typu sformułowania w celu uelastycznienia niezmiernie kazuistycznych tekstów ustaw podatkowych, drobiazgowo normujących rodzaje źródeł dochodów, katalogi zwolnień podmiotowych i przedmiotowych oraz ulg podatkowych. Wprowadzenie do treści przepisów prawa skarbowego sformułowań nieostrych stwarzało władzom skarbowym przestrzeń dla swobodnego uznania w podejmowaniu decyzji o ostatecznej wysokości podatku.

W opinii przedstawicieli nauki prawa skarbowego, zawarte w międzywojennym ustawodawstwie skarbowym zwroty niejasne stanowiły podstawę do niewyobrażalnych w dzisiejszych warunkach prawnopodatkowych luzów decyzyjnych i uznaniowości organów skarbowych. Taka konstrukcja przepisów prawnych była tym bardziej niekorzystna dla podatników, że wszystkie zobowiązania podatkowe powstawały w tym okresie w drodze wydawania nakazów płatniczych, czyli decyzji podatkowych. Dodatkową trudnością w ustaleniu jednoznacznego znaczenia treści poszczególnych przepisów utrudniała ogromna zmienność ustaw podatkowych, szczególnie tych, które normowały ważne z punktu widzenia budżetu państwa daniny. Zmiany z reguły dotyczyły tych elementów technicznych konstrukcji podatków, które miały wpływ na ustalenie ostatecznego ciężaru podatkowego. W konsekwencji nawet ówcześni pilni badacze prawa podatkowego przygotowując teksty do publikacji nie byli pewni, czy omawiają przepisy jeszcze obowiązujące, czy już zmieniane w toku prac legislacyjnych. 


\section{PURPOSES AND REASONS BEHIND THE USAGE OF VAGUE PHRASES IN THE TAX LAW REGULATIONS DURING THE INTERWAR PERIOD}

\section{Summary}

This paper is devoted to the issue of coding of vague phrases in tax-legal norms, i.e. specific legal categories which create legal language. Such expressions were known and used for specific purposes in the provisions of interwar tax law. Numerous representatives of the contemporary tax law science raised allegations in their publications related precisely to the use of such expressions in tax legislation. In their opinion, they contributed not only to the low linguistic level of the enacted laws but they also accounted for the excessive discretion of the tax authorities that assessed taxes. Vaguely formulated phrases such as: extraordinary circumstances, economic needs, relatively insignificant turnover, taxpayer's tax force or explicit ill will of the taxpayer constituted the premise for granting reliefs and exemptions in the most fiscally important taxes during the interwar period.

\section{RAISONS ET FINS DE L'UTILISATION D'EXPRESSIONS QUI NE SONT PAS PRECISEMENT DEFINIES DANS LA LEGISLATION FISCALE DANS LA PERIODE D'ENTRE-DEUX-GUERRES}

\section{Résumé}

Cet article est consacré à la question de l'introduction dans des codes fiscaux des expressions imprécises, constituant des catégories juridiques spécifiques créant un langage juridique. Ces expressions sont connues et aussi utilisées à des fins spécifiques dans les dispositions du droit fiscal de l'époque d'entre-deux-guerres. De nombreux représentants de la science du droit fiscal - dans leurs publications - soulevaient des allégations portant sur l'utilisation de telles expressions dans la législation fiscale. Selon leurs opinions, elles non seulement abaissaient la qualité du langage juridique, mais aussi donnaient aux autorités fiscales trop de liberté dans l'interprétation de la loi statuant sur la hauteur des impôts. Durant l'entre-deux guerres, les expressions imprécises telles que: circonstances extraordinaires, besoins économiques, chiffre d'affaires relativement faible ou puissance fiscale du contribuable ou manifestement mauvaise volonté du contribuable constituaient la base de décisions sur l'allégement des impôts les plus importants ou sur la libération de leur payement. 